\title{
ANALISIS KEKUATAN DAN KELEMAHAN OBYEK WISATA AIR PANAS PENATAHAN TABANAN UNTUK MENINGKATKAN JUMLAH KUNJUNGAN WISATAWAN
}

\author{
Gede Ari Wiryatama ${ }^{1}$, Nyoman Dini Andiani ${ }^{2}$ \\ Undiksha
}

\begin{abstract}
Abstrak
Penelitian ini bertujuan 1). Untuk mengetahui kekuatan dan kelemahan Obyek Wisata Air Panas Penatahan. 2). Untuk mengetahui upaya yang dilakukan pengelola dalam mengembangkan Obyek Wisata Air Panas Penatahan untuk meningkatkan jumlah kunjungan wisatawan. Penelitian ini adalah penelitian deskriptif kualitatif. Subjek dari penelitian ini adalah pengelola, masyarakat sekitar dan intansi terkait dari Obyek Wisata Air Panas Penatahan yang nantinya memberikan data mengenai pengembangan Obyek Wisata Air Panas Penatahan dan upaya yang dilakukan untuk meningkatkan jumlah kunjungan wisatawan. Sedangkan Objek dari penelitian ini adalah pengelolaan, peningkatan dan pengembangan Daya Tarik Wisata Air Panas Penatahan, yang membuat kemajuan wisata di daerah tersebut dengan potensi pariwisata yang di miliki Obyek Wisata Air Panas Penatahan agar nantinya dapat meningkatkan jumlah kunjungan wisatawan. Hasil Penelitian bahwa 1). Obyek Wisata Air Panas Penatahan memiliki kekuatan dan kelemahan yaitu kekuatan Obyek Wisata Air Panas Penatahan diantaranya adalah keadaan alam yang masih alami, memiliki fasilitas spa, villa dan restaurant dan lokasi yang strategis dekat dengan kota. Sedangkan kelemahan Obyek Wisata Air Panas Penatahan adalah kurangnya promosi yang dilakukan oleh pengelola, keterbatasan sarana dan prasarana, kurangnya kerjasama dengan biro perjalanan dan beberapa fasilitas yang mulai rusak dimakan usia. 2). Upaya pengelola dalam mengembangkan Obyek Wisata Air Panas Penatahan Tabanan untuk meningkatkan kunjungan wisatawan adalah dengan melakukan promosi melalui media cetak berupa brosur, menjaga kelestarian alam yang ada di Obyek Wisata Air Panas Penatahan, menjalin kerjasama dengan beberapa biro perjalanan dan menjaga fasilitas yang terdapat di Obyek Wisata Air Panas Penatahan.
\end{abstract}

Kata Kunci: Obyek Wisata Air Panas Penatahan, kekuatan dan kelemahan, pengelola.

\begin{abstract}
This study aims to know the strengths and weaknesses at the Tourism Object Hot Water Penatahan and know the efforts made by managers to develop Tourism Object Hot Water Penatahan to increase the number of tourists. This qualitative, used communities and related organizations in Tourism Object Hot Water Penatahan as respondents. This study fount that there were several strengths of the tourism object which are natural states, has spa facilities, villas and restaurant and a strategic location close to the city. On the other hand, the weaknesses identified were lack of promotion by the management, facilities and infrastructure, lack of cooperation with travel agencies and facilities begin to deteriorate because age. For the more, the effort made by the manager to develop this tourism object and to increase the number of tourist were to conduct a campaign through print media such as brochures, preserve tourism natural in Tourism Object Hot Water Penatahan, cooperative with several travel agencies, and maintain the facility located in Tourism Object Hot Water Penatahan Tabanan.
\end{abstract}

Keywords: Tourism Object Hot Water Penatahan, strengths and weaknesses, manager. 


\section{Pendahuluan}

Pada pengamatan yang dilakukan di Obyek Wisata Air Panas Penatahan Tabanan, bahwa daya tarik wisata yang dimiliki tidak hanya pemandian air panas melaikan terdapat juga daya tarik wisata alam yang mempesona. Obyek Wisata Air Panas Penatahan selain sebagai tempat pemandian air panas, juga memaparkan panorama alam yang sangat indah. Nikmatnya pemandian bernuansa alam di Air Panas Penatahan ini membuatnya berbeda dengan objek wisata pemandian air panas lainnya yang ada di Bali, tidak hanya sebagai tempat pemandian, namun juga merupakan wisata alam, dimana kita dapat memanjakan mata kita dengan menikmati pemandangan perbukitan yang indah dan asri serta hamparan persawahan di sekeliling area Obyek Wisata Air Panas Penatahan. Luas area Objek Wisata Air Panas Penatahan yang sekitar 1,5 hektar, akan membuat wisatawan semakin nyaman dan bebas menikmati keasrian suasana alam yang dihadirkan sehingga memberi kesan tersendiri bagi para wisatawan yang berkunjung. Tiket masuk Obyek Wisata Air Panas Penatahan sangat terjangkau dengan membayar, anak-anak Rp 10.000, dewasa Rp 25.000 untuk wisatawan lokal dan anak-anak Rp 50.000, dewasa Rp 100.000 untuk wisatawan asing.

Tingkat kunjungan di Obyek Wisata Air Panas Penatahan mengalami penurunan dari tahun ke tahun, dikarenakan kurangnya pengelolaan untuk peningkatan dan pengembangan yang dilakukan oleh pihak yang terkait. Perlunya peningkatan pengelolaan dan pengembangan untuk meningkatkan jumlah wisatawan yang berkunjung. Adapun hal yang perlu dilakukan pengelola adalah mempromosikan Obyek Wisata Air Panas Penatahan, memperbaharui segala fasilitas yang mendukung dan meningkatkan pengelolaan.

\section{Rumusan Masalah}

Adapun rumusan masalah dari penelitian ini sebagai berikut:

1. Apakah kekuatan dan kelemahan Obyek Wisata Air Panas Penatahan?

2. Bagaimana upaya yang dilakukan pengelola dalam mengembangkan Obyek Wisata Air Panas Penatahan untuk meningkatkan jumlah kunjungan wisatawan?

\section{Kajian Pustaka}

Beberapa dari penelitian terdahulu digunakan sebagai referensi dalam penelitian ini, yaitu: Penelitian yang dilakukan Eko Saputro (2008), dengan judul Potensi dan Pengembangan Objek Wisata Kampung Nelayan Pantai Drini di Kabupaten Gunungkidul. Hasil penelitian menyatakan bahwa Pengelolaan Objek Wisata Kampung Nelayan Pantai Drini telah dilaksanakan oleh pihak Dinas Pariwisata Kabupaten Gunungkidul selaku perencana, pengelola dan pelaksana kegiatan industri wisata karena selama ini belum ada pihak swasta yang bersedia mengelola kawasan objek wisata tersebut dengan alasan susahnya mendapat perijinan diantara instansi pemerintahan setempat, seperti pertanahan, 
perpajakan dan pembangunan. Pihak Pemerintah Kabupaten Gunung kidul melalui Dinas Pariwisata dan warga setempat telah melakukan berbagai upaya dalam mengembangkan kawasan Objek Wisata Kampung Nelayan Pantai Drini agar menjadi kawasan objek wisata andalan bagi wisatawan baik domestik maupun mancanegara. Dari permasalahan tersebut dapat disimpulkan bahwa peningkatan Obyek Wisata Air Panas Penatahan Tabanan perlu adanya pengembangan yang dilakukan oleh pemerintah, pengelola dan masyarakat sekitar untuk meningkatkan kunjungan wisatwan.

Penelitian yang dilakukan oleh Laila Fitria (2009), dengan judul Pengembangan dan Daya Tarik Obyek Wisata Pantai Ombak Mati di Bangsri Jepara Jawa Tengah. Dari hasil penelitian ini menyatakan bahwa Pantai Ombak Mati mampu menghasilkan produk yang menarik, serta dalam pelaksanaannya Pantai Ombak Mati dapat memberikan fasilitas yang memuaskan bagi wisatawan. Hal ini berarti Pantai Ombak Mati sebagai obyek wisata yang memberikan produk wisata alam bahari yang mempesona. Dengan adanya promosi kepada masyarakat umum, Pantai Ombak Mati akan menjadi Obyek Wisata yang akan ramai dikunjungi bayak wisatawan dari dalam maupun luar kota. Dari penjelasan di atas dapat disimpulkan bahwa pengembangan Obyek Wisata Air Panas Penatahan Tabanan perlu adanya peningkatan dan perbaikan fasilitas yang menunjang kegiatan wisatawan dan peran serta masyarakan sangat dibutuhkan untuk membantu kelestarian serta ikut berperan aktif di dalamnya agar dapat meningkatkan minat wisatawan yang berkunjung ke Obyek Wisata Air Panas Penatahan Tabanan.

Kemudian penelitian yang dilakukan oleh Dhita Triana Dewi (2010), dengan judul Analisis Kunjungan Obyek Wisata Water Blaster Kota Semarang. Dari hasil penelitian ini menyatakan bahwa, berdasarkan koefisien variabel penghasilan yang bertanda positif dapat disimpulkan bahwa Obyek Wisata Water Blaster merupakan barang normal, sehingga semakin tinggi penghasilan pengunjung akan semakin meningkat jumlah kunjungannya. Akan tetapi karena nilainya terlalu kecil Obyek Wisata Water Blaster merupakan barang normal yang cenderung inferior, dimana semakin tinggi penghasilan pengunjung maka mereka akan memilih tempat wisata lain yang memiliki tingkat prestise yang lebih tinggi. Untuk itu pihak pengelola Obyek Wisata Water Blaster perlu mengembangkan daya tarik wisata seperti permainan, meningkatkan dan memperbaiki fasilitas tetapi hal tersebut perlu menjaga competitive advantage seperti cost advantage, karena pengembangan akan menaikkan harga untuk berkunjung ke Obyek Wisata Water Blaster sehingga akan menurunkan jumlah kunjungan. Dari penjelasan yang telah disampaikan bahwa Obyek Wisata Air Panas Penatahan Tabanan perlu adanya promosi mengenai daya tarik wisata, peningkatan dan pengembangan fasilitas dan atraksi wisata yang dapat menarik minat wisatawan agar berkunjung ke Obyek Wisata Air Panas Penatahan Tabanan. 
Persamaan penelitian ini dengan penelitian yang pernah dilakukan sebelumnya ialah permasalahan mengenai upaya pengembangan obyek wisata untuk peningkatan kunjungan wisatawan. Terkait dengan tingkat minat kunjungan wisatawan yang menurun dan permasalahan hambatan yang dihadapi pengelola untuk meningkatkan kunjungan wisatawan.

\section{Metode Penelitian}

\subsection{Rancangan Penelitian}

Penelitian ini merupakan penelitian deskriptif kualitatif yang menggambarkan apa yang ada dilapangan dan mengupayakan penggambaran data dalam bentuk pemaparan. Dalam penelitian ini menghasilkan data mengenai kekuatan dan kelemahan serta upaya pengelola dalam meningkatkan jumlah kunjungan wisatawan di Obyek Wisata Air Panas Penatahan. Dengan menggunakan sumber data primer dan sekunder serta melalui teknik pengumpulan data seperti observasi, wawancara dan dokumentasi.

\subsection{Subjek dan Objek Penelitian}

Subjek dari penelitian ini adalah pengelola, masyarakat sekitar dan intansi terkait dari Obyek Wisata Air Panas Penatahan Tabanan yang nantinya memberikan data mengenai kekuatan dan kelemahan Obyek Wisata Air Panas Penatahan dan upaya yang dilakukan pengelola untuk meningkatkan jumlah kunjungan wisatawan.

Objek dari penelitian ini adalah pengelolaan, peningkatan dan pengembangan Daya Tarik Wisata Air Panas Penatahan Tabanan yang membuat kemajuan wisata di daerah tersebut dengan potensi pariwisata yang di miliki Obyek Wisata Air Panas Penatahan agar nantinya dapat meningkatkan jumlah kunjungan wisatawan.

\subsection{Sumber Data}

Sumber data yang dipergunakan dalam penelitian ini adalah seagai berikut:

Sumber data primer yaitu data yang diperoleh langsung dari narasumber yang mengelola Obyek Wisata Air Panas Penatahan Tabanan dalam melakukan upaya pengembangan dan meningkatkan jumlah kunjungan wisatawan. Dalam penelitian ini yang dijadikan sumber primer adalah pengelola, masyarakat dan intansi terkait di Obyek Wisata Air Panas Penatahan Tabanan.

Data sekunder yaitu data yang dapat memperkuat penelitian ini dengan pengambilan data yang sudah terkompilasi dalam buku yang berkaitan atau instansi di daerah studi maupun melalui pencatatan data atau hasil penelitian dari pihak terkait yang mendukung penelitian. 


\subsection{Teknik Pengumpulan Data}

Dalam penelitian ini digunakan tiga instrument penelitian yaitu: Observasi yaitu Teknik ini dilakukan secara langsung ke lokasi Obyek Wisata Air Panas Penatahan Tabanan untuk memperoleh data tentang upaya pengelola dalam mengembangkan dan meningkatan jumlah kunjungan wisatawan dan hambatan yang di alamai dalam upaya pengembangan dan cara penangulangan yang dilakukan oleh pengelola di Obyek Wisata Air Panas Penatahan Tabanan. Wawancara yaitu Teknik ini dilakukan dengan cara tanya jawab terhadap narasumber yang berhubungan dengan penelitian untuk mengumpulkan data dan mendapatkan informasi mengenai "Analisis Kekuatan dan Kelemahan Obyek Wisata Air Panas Penatahan Tabanan untuk Meningkatkan Jumlah Kunjungan Wisatawan". Wawancara ini ditunjukkan kepada pengelola, masyarakat sekitar dan intansi terkait dalam pengembangan Obyek Wisata Air Panas Penatahan Tabanan. Dokumentasi yaitu Teknik pengumpulan dokumentasi dilakukan dengan cara mengumpulkan data seperti dokumen dan referensi yang dapat menunjang penelitin serta dokumentasi foto yang memperkuat penelitian.

\section{Hasil Penelitian dan Pembahasan}

Adapun hasil penelitian yang didapat dari rumusan masalah yang diangkat yaitu analisis kekuatan dan kelemahan Obyek Wisata Air Panas Penatahan Tabanan untuk meningkatkan jumlah kunjungan wisatawan. Adapun hasil penelitian dan pembahasan tersebut antara lain:

\subsection{Kekuatan Obyek Wisata Air Panas Penatahan}

1. Keadaan alam yang masih alami

Keindahan alam terlihat dari perbukitan yang memiliki pepohonan yang rindang dan hamparan persawahan di sekitar obyek wisata merupakan daya tarik tersendiri bagi wisatawan. Alam yang masih asli dan indah yang didukung dengan suasana pedesaan memberikan udara yang sejuk dan bersih membuat nyaman bagi wisatawan yang berkunjung. Dengan keadaan alam yang ada di obyek wisata ini sangat mendorong dalam pengembangan dan menjadi keunikan serta keunggulan tersendiri bagi Obyek Wisata Air Panas Penatahan selain daya tarik wisata yang ada yaitu pemandian air panasnya.

2. Fasilitas pendukung Obyek Wisata Air Panas Penatahan

Di obyek wisata ini terdapat spa pemandian air panas, villa dan restaurant yang mendukung obyek wisata ini. Dengan fasilitas yang ada akan memanjakan setiap wisatawan yang berkunjung ke obyek wisata ini.

3. Jarak tempuh obyek wisata yang dekat dengan Kota 
Lokasi Obyek Wisata Air Panas Penatahan Tabanan sangat mudah dijangkau dari Kota Tabanan, jarak dari Kota Tabanan adalah $13 \mathrm{Km}$. Bagi wisatawan yang akan menuju obyek wisata ini tidak terlalu sulit untuk menemui lokasi obyek wisata dikarenakan adanya petunjuk jalan yang di pasang di beberapa titik yang akan mempermudah wisatwan yang akan berkunjung ke obyek wisata ini. Disepanjang jalan menuju obyek wisata ini, wisatawan bisa melihat hamparan persawahan yang indah, karena salah satu sumber mata pencaharian warga Tabanan adalah sebagai petani. Perjalanan dari Kota Tabanan kurang lebih ditempuh dalam waktu setengah jam.

4. Memiliki tempat parkir yang luas

Obyek Wisata Air Panas Penatahan memiliki tempat parkir yang lumayan luas yang dapat menampung kendaraan wisatawan yang berkunjung. Wisatawan yang berkunjung juga tidak perlu membayar parkir di obyek wisata ini.

\subsection{Kelemahan Obyek Wisata Air Panas Penatahan}

1. Promosi obyek wisata yang masih kurang

Perlunya promosi melalui media elektronik berupa web untuk mempermudah masyarakat luas mengetahui tentang daya tarik wisata yang dimiliki Obyek Wisata Air Panas Penatahan

2. Keterbatasan sarana dan prasarana

Dana pengembangan dan pembangunan Obyek Wisata Air Panas Penatahan Tabanan masih mengandalkan dana dari penjualan tiket masuk oleh wisatawan yang berkunjung serta dana dari pemerintah yang masih kurang untuk melakukan pembangunan dan pengembangan. Keterbatasan membuat pembangunan dan pengembangan Obyek Wisata Air Panas Penatahan terhambat.

3. Kurangnya tenaga kerja professional dalam pengelolaan

Tenaga kerja di obyek wisata ini tidak semuanya berpendidikan pariwisata sehingga pengelolaan masih kurang. Kurangnya pengelola yang bisa berbahasa asing, sehingga wisatawan asing jika tidak melalui biro perjalanan tidak bisa mengetahui tentang obyek wisata ini.

4. Perlunya pembaharuan fasilitas

Fasilitas perlu diperbaharui agar wisatawan yang berkunjung merasa nyaman. Beberapa fasilitas sudah mulai rusak karena dirmakan usia. Perlunya penambahan fasilitas tempat duduk di beberapa titik agar wisatawan yang berkunjung dapat beristirahat sambil menikmati suasana di obyek wisata ini. 
Upaya pengelola dalam mengembangkan Obyek Wisata Air Panas Penatahan untuk meningkatkan jumlah kunjungan wisatawan

1. Promosi menggunakan brosur yang disebarkan di obyek wisata yang ada di Tabanan. Promosi ini dilakukan untuk memperkenalkan daya tarik wisata yang ada di Obyek Wisata Air Panas Penatahan, bahwa terdapat pemandian air panas yang layak untuk dikunjungi wisatawan selain obyek wisata yang ada di Kabupaten Tabanan.

2. Menjaga keadaan alam disekitar obyek wisata agar tetap alami, indah dan asri. Ini dilakukan karena selain daya tarik wisata yang ada yaitu pemandian air panas salah satu daya tarik yang dirasa dapat meningkatkan jumlah kunjungan wisatawan adalah wisata alamnya, dikarenakan disekitar obyek wisata ini terdapat perbukitan dengan pohonnya yang rindang dan hijau serta hamparan persawahan yang ada di sekitar obyek wisata ini yang menjadi daya tarik tersendiri bagi wisatawan yang berkunjung.

3. Menjalin kerjasama dengan biro perjalanan agar nantinya Obyek Wisata Air Panas Penatahan sebagai salah satu tujuan wisatawan untuk dikunjungi.

4. Menjaga dan memperbaharui fasilitas penunjang wisatawan yang berkunjung agar wisatawan merasa betah dan nyaman berada di obyek wisata ini.

Berdasarkan hasil penelitian tentang kekuatan yang dimiliki di Obyek Wisata Air Panas Penatahan, beberapa hal yang mendukung daya tarik wisata yang ada sebagai obyek wisata, yaitu dari segi alamnya selain air panas yang terdapat di lokasi ini. Obyek wisata ini memiliki pemandangan alam yang indah dan masih tampak alami. Dengan keindahan alam yang ada di obyek wisata ini dapat dijadikan sebagai salah satu daya tarik wisata alam.

Obyek Wisata Air Panas Penatahan memiliki beberapa kelemahan khususnya dalam bidang promosi. Kegiatan promosi sangat berperan penting dalam pengembangan obyek wisata, karena dengan adanya promosi maka suatu produk wisata akan mampu terjual dan dapat dikenal oleh masyarakat luas.

Pengelola perlu melakukan promosi melalui media elektronik agar wisatawan luas dapat mengetahui daya tarik wisata yang terdapat di obyek wisata ini, bekerja sama dengan biro perjalanan khususnya yang ada di bali dan membenahi fasilitas yang rusak agar wisatawan menikmati berada di obyek wisata ini.

\section{Penutup}

\subsection{Simpulan}

Dari hasil penelitian dan pembahasan yang dipaparkan terkait dengan analisis kekuatan dan kelemahan serta upaya dari pengelola untuk mengembangkan obyek wisata ini maka dapat disimpulkan beberapa hal sebagai berikut: 
Obyek Wisata Air Panas Penatahan memiliki beberapa kekuatan diantaranya keadaan alam yang masih alami yang dapat dimanfaatkan pengelola sebagai daya tarik wisata alam, memiliki fasilitas spa pemandian air panas, villa dan restaurant yang dapat dimanfaatkan bagi wisatawan yang berkunjung dan lokasi obyek wisata yang strategis dekat dengan Kota Tabanan. Sedangkan beberapa kelemahan di Obyek Wisata Air Panas Penatahan yaitu kurangnya promosi yang dilakukan pengelola karena pengelola baru melakukan promosi melalui media cetak berupa brosur dan diperlukan promosi melalui media elektronik berupa situs web agar masyarakat luas dapat dengan mudah mengetahui daya tarik wisata yang terdapat di Obyek Wisata Air Panas Penatahan, keterbatasan sarana dan prasaranan, kurangnya kerja sama dengan pihak biro perjalanan pariwisata yang ada di Bali dan fasilitas yang mulai rusak dimakan usia dan upaya yang telah dilakukan oleh pihak pengelola Obyek Wisata Air Panas Penatahan yaitu dengan melakukan promosi melalui media cetak berupa brosur, menjaga kelestarian alam yang berada di sekitar obyek wisata, menjalin kerjasama dengan beberapa biro perjalanan dan menjaga fasilitas yang terdapat pada Obyek Wisata Air Panas Penatahan.

\subsection{Saran}

Setelah melakukan penelitian di Obyek Wisata Air Panas Penatahan dapat disarankan beberapa hal sebagai berikut:

1. Untuk peneliti selanjutnya mengenai Obyek Wisata Air Panas Penatahan diharapkan meneliti lebih spesifikasi dan mendetail selain menganalisis kekuatan dan kelemahan Obyek Wisata Air Panas Penatahan untuk meningkatkan jumlah kunjungan wisatawan.

2. Untuk pengelola Obyek Wisata Air Panas Penatahan dengan daya tarik wisata yang dimiliki perlunya pelestarian dan menjaga keadaan Obyek Wisata Air Panas Penatahan agar obyek wisata ini bisa terus dinikmati dan diminati oleh wisatawan.

3. Untuk biro perjalanan diharapkan Obyek Wisata Air Panas Penatahan sebagai salah satu tujuan dari rute wisata perjalanan yang dilakukan agar wisatawan mengetahui Obyek Wisata Air Panas Penatahan layak untuk dikinjungi selain obyek wisata yang ada di Kabupaten Tabanan.

4. Untuk pemerintah daerah agar lebih memperhatikan keadaan Obyek Wisata Air Panas Penatahan agar tetap layak dijadikan obyek wisata dan memberi dukungan berupa bantuan kepada pihak pengelola agar dapat meningkatkan pembangunan dan pengembangan serta meningkatkan kualitas di Obyek Wisata Air Panas Penatahan Tabanan. 


\section{Daftar Pustaka}

Dinas Pariwisata Daerah Kabupaten Tabanan. Jumlah kunjungan wisatawan di Obyek Wisata Air Panas Penatahan tahun 2011-Mei 2014, (observasi tanggal 8 September 2014).

Eko Saputro. 2008. Potensi dan Pengembangan Obyek Wisata Kampung Nelayan Pantai Drini di Kabupaten Gunungkidul. Universitas Sebelas Maret.

Laila Fitria. 2009. Pengembangan dan Daya Tarik Obyek Wisata Pantai Ombak Mati di Bangsri Jepara Jawa Tengan. Universitas Sebelas Maret.

Dhita Triana Dewi. 2010. Analisis Kunjungan Obyek Wisata Water Blaster Kota Semarang. Universitas Diponegoro.

http://Pariwisata Bali dan Global (Bali and Global Tourism) Pengertian Obyek dan daya tarik Wisata.html, (diakses pada tanggal 16 September 2014).

http://pariwisata teknologi Definisi Daya Tarik Wisata.html, (diakses pada tanggal 16 September 2014).

http://pengertian-swot.html, (diakses pada tanggal 16 September 2014).

http://Pengertian pengelolaan.html, (diakses pada tanggal 16 September 2014).

http://Pengertian Pariwisata Wiki Pariwisata.html, (diakses pada tanggal 17 September 2014).

http://Pengertian Promosi Menurut para Ahli Pengertian Ahli.htm, (diakses pada tanggal 17 September 2014).

Primayanti Devi, 2013. Laporan Obyek Wisata Air Panas Banjar. Singaraja. 